\title{
The influence of wage, age and experience to labor productivity in construction works in Kota Langsa, Aceh
}

\author{
Ipak Neneng Mardiah Bukit ${ }^{1, *}$, Yulina Ismida $^{1}$, Rizcy Maulana ${ }^{1}$, and Muhammad Nasir ${ }^{1}$ \\ ${ }^{1}$ Civil Engineering Department, Engineering Faculty, Samudra University, Meurandeh Kota Langsa, Indonesia
}

\begin{abstract}
Construction work, as well as other production process depends on how people work towards it. The success of the work is determined by labor productivity. Labor productivity is affected by many factors such as human factors, environment, labor condition, leadership, type of work, level of difficulty etc. This article will discuss how these aspects influence the value of labor productivity. We limit our research on wage, age and experience from 15 to 30 workers in the brick work. The research is held in 4 construction sites in Kota Langsa, Aceh, Indonesia in late 2016 until early 2017. We observe the effective time, time of contribution, ineffective time work and the work volume. Productivity is obtained by dividing the work volume and the effective time work. The result shows that the amount of wage influences the labor productivity. Nonetheless, we found that age and experience do not affect labor productivity. Interestingly, the experience workers in any ages will increase the value of labor productivity.
\end{abstract}

\section{Introduction}

Kerzner [1] states that the real failure of project management is when the outputs or results are not what we expected. He also studied that in 1990's a failure is attributed to poor morale, poor motivation, poor human resources, no employee commitment and poor productivity. Borchering and Liaou in Gundecha [2] state that productivity is related with inputs and outputs of work. That is the expression of what people provide in the end of the work depends on how they do their work. Productivity is also understood as how many hours people need to deliver a unit of activity which will determine how long the work could be finished. Planning the productivity, especially labor productivity is believed will give effect to project planning and schedule. People who work in construction industry tend to optimize their ability according to the project schedule, because time is very delicate in the industry. PMI [3] guides that resource productivity has an effect on the activity duration, thus it is difficult to be estimated in project planning phase. Furthermore, planning productivity means project management is right on track.

Labor is not a simple resource to be organized. Numerous factors give influence in these resources such as environment, local tradition, experience, age, leadership, wages, etc. Kaming (1997) in Ervianto [4] classifies the influential factors of labor productivity in 4 (four) categories, i.e. 1). Method and technology; 2).
Project management in site; 3). Work environment; and 4). Human factors (wage rate, work satisfaction, profit share, worker-supervisor relationship, workerworkerrelationship and discipline). These factors could give positive or negative consequences to labor productivity.

The past studies try to measure or calculate the impact of these factors to productivity; however it is hard to standardize this impact [2]. This article discusses how the factors influence the labor productivity positively or negatively by measuring labor productivity in site. We limit this research in three factors i.e. wages, ages and experiences, since they are considered as sensitive aspects to human factors. The sample is 15 workers for wages and 30 workers for ages and experiences. The observation is held on brick work activity. The result found that the higher of wages give a better productivity. Interestingly as people getting older, their productivity is associated with their working experiences. An older worker with good experiences provides a better productivity. A younger worker with good experiences gives a better productivity as well. But an older one with lack of experience will be less productive as well as a non-experience young worker.

\section{Labor Productivity Definitions}

Productivity is an important aspect on project schedule. It is related to worker capability that will determine the

Corresponding author: ipakbukit@unsam.ac.id 
project execution time. Productivity also encourages the project performs well. Datta, Guthrie \& Wright [5] from Delery \& Shaw (2001) state labor productivity is the key indicator of workforce performance. This means the labor productivity confirms project schedule process result as plan, or the people work well and the schedule runs properly.

Calculating the project schedule is unique for every project planning. The good labor productivity cannot be repeated in different place and different situation. Koch \& McGrath [6] study that superior productivity cannot be imitated, cannot be replicated easily, uniquely valuable in given firm setting and may add unique value to strategic inputs factors. This argument gives reason to emphasize the project productivity in order to create a firm's competitive position and to reach its project goals.

\section{Research Goal(s)}

Labor productivity as other project performance indicators is affected by various factors that could bring the project performance into positive or negative impacts. Wolgemuth et al [7] found that poor health and nutritional status of employee may reduce labor productivity. Labor health condition related to how much wages they earn to supply good nutrition. Therefore we put wages as one of the influential factors on labor productivity.

Other factor is age, because human grows older. Generally speaking, worker's energy decreases by time of age. Hence, it is a significant factor in labor productivity. We want to see whether this factor will affect their productivity or not.

Koch \& McGrath [6] state there are three resources as predictor project performances; they are physical resources, organizational resources, and human resources. Human resources are representing the knowhow and skills related working in an organization. Skills are related to worker's experiences. Worker with experiences may have more skills than others. However, we need to clarify whether experience influence labor productivity or not.

Based on the background, subsequently this research aims to figure out how wages, ages and experiences affect the productivity in construction works. The research is held on 4 (four) construction project sites in Kota Langsa, Aceh during late 2016 until the early 2017.

\section{Methodologies}

Research methodology is descriptive, observation and interview. Wages observation is held in 4 (four) sites, while ages and experiences observation is held in 2 (two) project sites altogether. Data collection is done by three steps; 1 . Preliminary survey, in order to get a fit location; 2. Interview with the laborers; and 3. Observation of the actual time work.

Data collected is: number of worker in sites, effective time work (ET), ineffective time (IT), and contribution time (CT). The observation is done in 5 to 6 days, depends on the number of data needed.

Work volume is obtained by observing the worker's brick work achievement per day in sites. The volume is measured for every ET. ET is calculated from the start time of the activity until it stops for resting, and continues until the end of work day during 5 to 6 days. It is measured using measuring tool for every ET. The result is an average volume in $\mathrm{m}^{2}$.

Productivity of this work is calculated using the formula below [8]:

$$
\operatorname{Pr}=\text { Volume } / \text { n.ET }
$$

Where

$\mathrm{Pr}=$ productivity $\left(\mathrm{m}^{2} /\right.$ hour $)$

$\mathrm{n}=$ number of worker

$\mathrm{ET}=$ effective time work (minutes)

\section{Results and Discussion}

\subsection{Results}

The results of the research can be seen in tables and figures below.

Table 1. Summary of ET, CT, IT, volume \& productivity by wages

\begin{tabular}{|c|c|c|c|c|c|c|}
\hline$\frac{0}{0}$ & 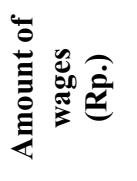 & 因兽 & 记兽 & 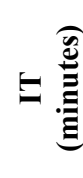 & 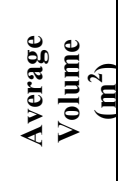 & 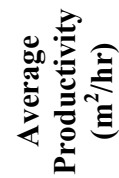 \\
\hline 1 & 100,000 & 330 & 46 & 125 & 8.88 & 1.615 \\
\hline 2 & 80,000 & 328 & 40 & 116 & 8.55 & 1.564 \\
\hline 3 & 80,000 & 255 & 67 & 158 & 7.54 & 1.774 \\
\hline 4 & 80,000 & 250 & 48 & 182 & 5.84 & 1.402 \\
\hline 5 & 80,000 & 244 & 55 & 181 & 7.24 & 1.780 \\
\hline 6 & 80,000 & 271 & 47 & 173 & 8.61 & 1.906 \\
\hline 7 & 80,000 & 223 & 41 & 231 & 5.95 & 1.601 \\
\hline 8 & 80,000 & 236 & 68 & 176 & 6.91 & 1.757 \\
\hline 9 & 80,000 & 278 & 79 & 123 & 8.52 & 1.839 \\
\hline 10 & 120,000 & 295 & 73 & 117 & 8.7 & 1.769 \\
\hline 11 & 120,000 & 304 & 66 & 113 & 9.03 & 1.782 \\
\hline 12 & 120,000 & 233 & 89 & 160 & 11.9 & 3.064 \\
\hline 13 & 120,000 & 280 & 62 & 141 & 5.78 & 1.239 \\
\hline 14 & 120,000 & 202 & 88 & 206 & 6.27 & 1.862 \\
\hline 15 & 120,000 & 265 & 91 & 133 & 6.07 & 1.374 \\
\hline
\end{tabular}

The data collected for wages was taken from 4 (four) projects. However, the wages range does not vary in the area; therefore it is unnecessary to obtain more 
respondents in this category. The result of the observation in wages can be seen in figure 1 .

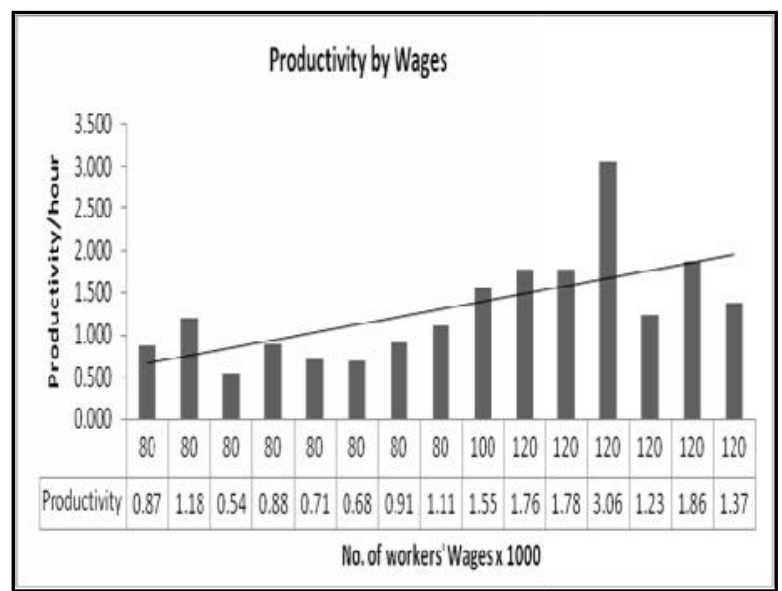

Fig. 1. Productivity vs. wages

This Fig. 1 shows that wages influence the productivity value. Worker with higher wage will work faster compare to the one who earns smaller wage. The trend describes the value of productivity significantly increases. It tells us that people will work as how he is rewarded. Subsequently, wage influences the value of labor productivity.

Table 2. Summary of ET, CT, IT, volume \& productivity by Age and Experiences

\begin{tabular}{|c|c|c|c|c|c|c|c|}
\hline \multirow[b]{2}{*}{ 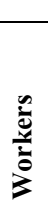 } & \\
\hline & $\stackrel{80}{4}$ & 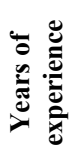 & 四泀 & 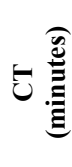 & E蔨 & 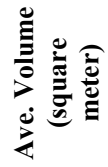 & 递胥 \\
\hline 1 & 23 & 6 & 236 & 176 & 68 & 6.91 & 1.757 \\
\hline 2 & 26 & 7 & 223 & 231 & 41 & 5.95 & 1.601 \\
\hline 3 & 30 & 12 & 283 & 218 & 44 & 5.60 & 1.187 \\
\hline 4 & 31 & 10 & 258 & 165 & 55 & 5.54 & 1.288 \\
\hline 5 & 32 & 7 & 250 & 182 & 48 & 5.84 & 1.402 \\
\hline 6 & 32 & 7 & 283 & 157 & 35 & 5.80 & 1.230 \\
\hline 7 & 32 & 11 & 175 & 205 & 65 & 7.54 & 2.585 \\
\hline 8 & 32 & - & 240 & 175 & 40 & 5.23 & 1.308 \\
\hline 9 & 33 & 8 & 255 & 158 & 67 & 7.54 & 1.774 \\
\hline 10 & 33 & 11 & 248 & 192 & 45 & 4.06 & 0.982 \\
\hline 11 & 34 & 7 & 252 & 183 & 50 & 3.87 & 0.921 \\
\hline 12 & 36 & 9 & 273 & 210 & 63 & 6.01 & 1.321 \\
\hline 13 & 36 & 14 & 260 & 175 & 45 & 6.84 & 1.578 \\
\hline 14 & 37 & 10 & 244 & 181 & 55 & 7.24 & 1.780 \\
\hline 15 & 38 & 10 & 271 & 173 & 47 & 8.61 & 1.906 \\
\hline 16 & 38 & 12 & 240 & 175 & 40 & 6.13 & 1.533 \\
\hline 17 & 38 & 15 & 232 & 197 & 41 & 6.53 & 1.689 \\
\hline 18 & 40 & 19 & 217 & 222 & 48 & 5.71 & 1.579 \\
\hline 19 & 40 & 9 & 255 & 195 & 28 & 7.64 & 1.798 \\
\hline 20 & 40 & 14 & 236 & 210 & 62 & 7.08 & 1.800 \\
\hline 21 & 41 & 10 & 215 & 205 & 35 & 4.93 & 1.376 \\
\hline 22 & 42 & 18 & 328 & 116 & 40 & 8.55 & 1.564 \\
\hline 23 & 42 & 13 & 298 & 150 & 40 & 8.46 & 1.703 \\
\hline 24 & 46 & 13 & 275 & 140 & 65 & 6.58 & 1.436 \\
\hline 25 & 46 & 15 & 265 & 175 & 45 & 6.66 & 1.508 \\
\hline 26 & 48 & 16 & 278 & 123 & 79 & 6.06 & 1.308 \\
\hline 27 & 51 & 18 & 265 & 185 & 30 & 8.36 & 1.893 \\
\hline 28 & 52 & 20 & 227 & 206 & 48 & 8.52 & 2.252 \\
\hline 29 & 54 & 18 & 277 & 166 & 37 & 7.78 & 1.685 \\
\hline 30 & 62 & 23 & 252 & 175 & 60 & 6.79 & 1.617 \\
\hline
\end{tabular}

The data collected based on ages and experiences was taken from 2 (two) projects, however we have enough reliable amount of workers. The workers' ages are varying from the youngest, 23 years old and the oldest, 62 years old, while their experiences are from 6 to 23 years. The trend of these categories can be seen in figures 2 and 3 as follow.

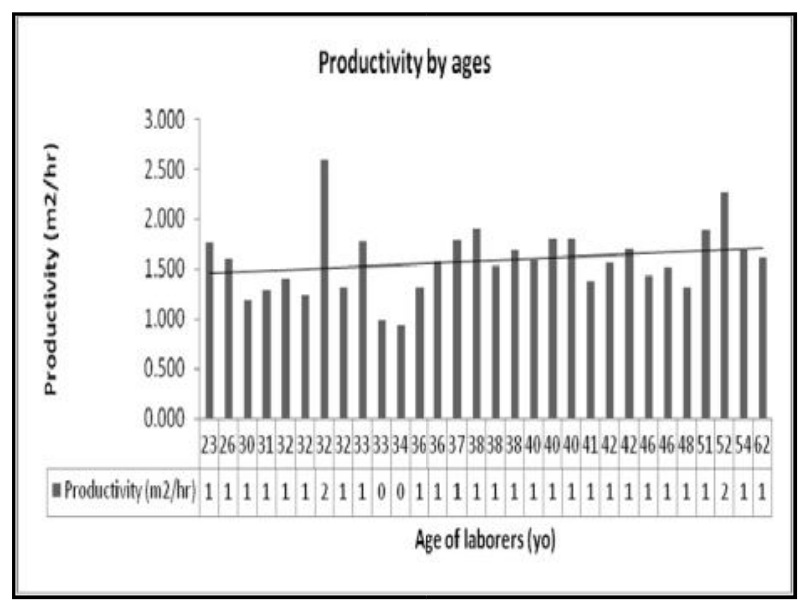

Fig. 2. Productivity vs. ages

Fig.2. shows that getting older does not cause workers to be more productive. It tells us that age does not significantly influence the value of labor productivity. The trend just slightly increases.

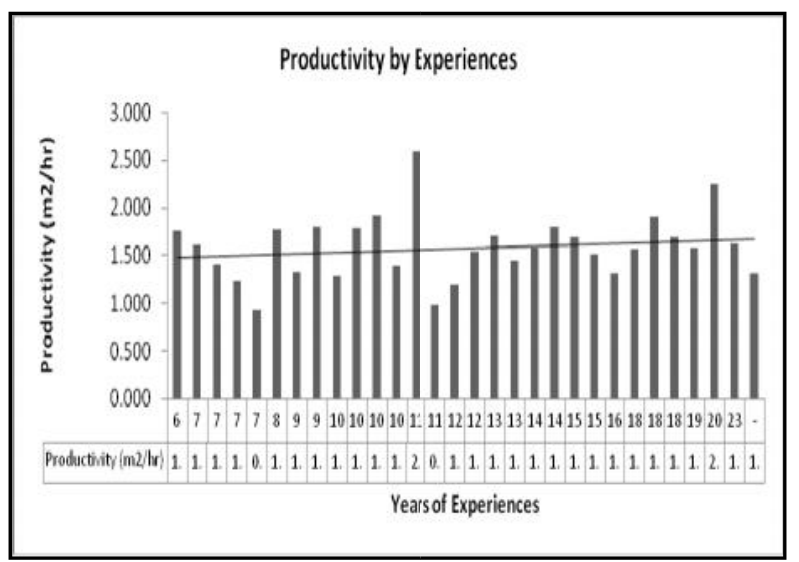

Fig. 3. Productivity vs. year of experiences

Fig.3 shows that the level of productivity on experience is fluctuated. The longest experience worker is not the most productive worker.

However, if we combine both figures we can see in fig. 4 below. 


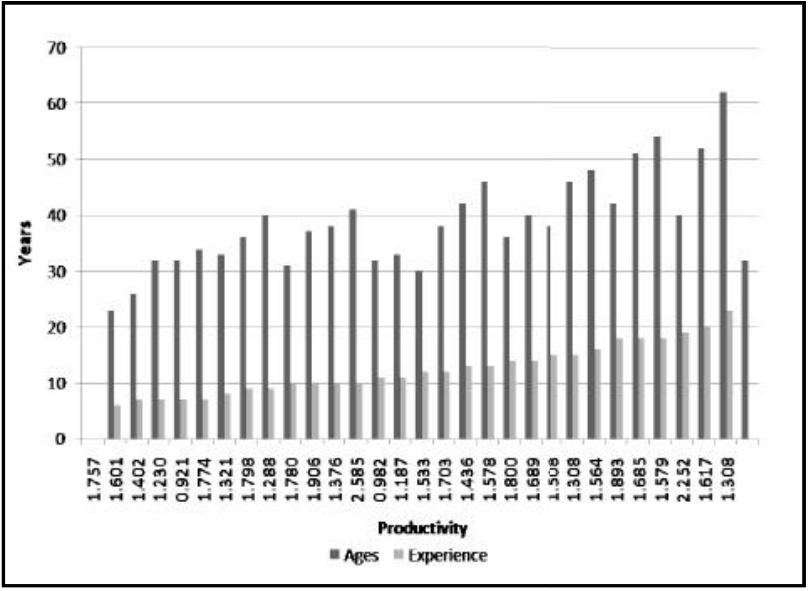

Fig.4. Productivity vs. year of age and experiences

Fig.4. shows that old worker with good experience apparently has a better productivity compares to the one who doesn't. It also applies to younger worker. It shows that experience in any ages will affect the level of productivity.

\subsection{Discussion}

The trend of wages to productivity is quite influential. Even though there is discrepancy between workers with Rp,120,000,- per day rate, the trend convinces that the more wages the worker earns, the more productive he is. This is a sign that worker will work faster if they are well paid.

In contrary, worker's ages and experiences' trend just slightly increase the productivity. The older is a bit more productive than the younger one, but some younger workers with good experience have better productivity.

This is related with skills and work ability. Young worker has a good skill because he has good experience. While the older labor gains working skills from their long experience. Experience determines whether workers have enough skills in construction or not, therefore they have high productivity.

The best ages of worker in construction are in their 30 's. In this age, stable productivity is reached. On the other hand, old and young workers with less experience are usually less productive. Obviously, experience gives influence to labor productivity, both at the young and the old age.

\section{Conclusions}

In conclusion, the wages of worker is influential to labor productivity. The trend shows that the significant increases in labor productivity level caused by increasing wage. The age doesn't give significant influence to labor productivity, neither does experience. However, if both ages and experiences combined, they show interesting fact that workers with experience is more productive, even though they are still at the young age. Thus we believe that worker who lacks experience is less productive. Hence, experience at any ages is influential to labor productivity.

In this paper, we would like to express our appreciation and thankfulness to our colleagues at Civil Department, Engineering Faculty, Samudra University. We also want to convey highest gratitude to the SIBE Conference 2017 ITB Bandung for giving us the remarkable opportunity. Additionally, we would like to appreciate the entire project's stakeholders in project sites which with their cooperation who allow us to collect the data smoothly.

\section{References}

1. H. Kerzner, Project Management A System Approach to Planning, Schedulling and Controlling, Eight Edition, Jhon Wiley \& Sons, (2003).

2. M.M. Gundecha, Study of Factors Affecting Labor Productivity at a Building Construction Project in the USA: Web Survey, Master Thesis, the Faculty of Agriculture and Applied Science, North Dakota University, Fargo, North Dakota, (2012).

3. PMI, Project Management Book of Knowledge, Third Edition, Project Management Institute Inc., (2004).

4. W.L. Ervianto, Peng. Prod. Kel. PB dlm Proy Konst, Jurnal Teknik Sipil, 9(1), pp.31-42, (2008).

5. D.K. Datta, J.P. Guthrie, \& P.M. Wright, HRM and Lab. Prod.: Does Ind. Matter, Academy of Management Journal, 48(1), pp.135-145, (2005).

6. M.J. Koch, \& R.G. McGrath, Imp. Lab. Prod.: HRM Policies Do Matter, Strategic Management Journal, 17, pp.335-354, (1996).

7. J.C. Wolgemuth, M.C. Latham, A. Chesher, \& D.W.T. Crompton, Wkr Prod. and Nutrition. Stat. of Kenyan Road Constr. Lab., The American Journal of Clinical Nutrition, 36, pp.68-78, (1982).

8. Hansen, Menghitung Produktifitas Pekerja, Wordpress.com, retrieved in August 2017, from https://hansenkammer.wordpress.com/2009/08/21/m enghitung-produktivitas-pekerja/, (August $21^{\text {st }}$ 2009). 